\title{
Experimental evaluation of the operational properties of snowmobile motor vehicles
}

\author{
Vladislav Klubnichkin ${ }^{1, *}$, and Evgeny Klubnichkin ${ }^{1}$ \\ ${ }^{1}$ Bauman Moscow State Technical University, Department of Wheeled Vehicles, 105005 Moscow, \\ Russian Federation
}

\begin{abstract}
The article demonstrates the results of the experimental estimate of the speed and load modes as well as operational properties of the oversnow equipment during which a large number of parameters and indicators allowing for their use during designing of new generation of oversnow vehicles have been determined. This work demonstrates the results of the tests in determining speed and brake properties, as well as stability and controllability of the Russkaya Mekhanika's oversnow vehicles, models RM Buran Leader, RM Tayga Varyag 550, RM Tayga Patrul 800 SWT, RM Vector 551i and over companies' oversnow vehicles, models BRP Lynx Xtrim Commander 800 E-TEC, Arctic Cat Pantera 7000 XT LTD, Polaris 800 Titan Adventure 155.
\end{abstract}

The experimental estimate procedure has combined tests conducted to estimate speed and brake properties, as well as stability and controllability of the oversnow vehicles in critical movement modes.

The speed properties include the following indicators: maximum speed; acceleration to maximum speed, to speed of $60 \mathrm{~km} / \mathrm{h}$ and to speed of $30 \mathrm{~km} / \mathrm{h}$. The ride was conducted on an even snow-covered area, a tester accelerated to a maximum speed using $100 \%$ of power. The tests for each oversnow vehicle consisted of four rides over the same track with variable directions of movement in twins [1]. The maximum speed of the oversnow vehicle was determined as an arithmetic average of the conducted measurements.

The barking length of the oversnow vehicles was determined by results of four measurements (rides) conducted in two mutually opposite directions. The movement speed at the braking start moment was established against a standard speed meter. Additional monitoring of the measurement results was done with use of the third-generation GPSbased data recording system VBOX $3 i$ [2].

The tests were conducted in critical movement modes to determine indicators which characterize controllability and stability of the oversnow vehicles [3]. Test of "Turn over set radius $\mathrm{R}_{\Pi}=25 \mathrm{~m}$ " are intended to determine maximum speed of maneuver when entering a turn. "Elk tests $\mathrm{S}_{\Pi}=16 \mathrm{~m}$ " are intended to determine maximum speed of maneuver when changing movement trajectory within a limited path. The oversnow vehicle's maximum speed during maneuver was determined as an arithmetical average of speeds during three rides with a maximum speed at which the ground marking was not overrun. The marking of

${ }^{*}$ Corresponding author: vklubnichkin@gmail.com 
the sites for Tests of turn over set radius $\mathrm{R}_{\Pi}=25 \mathrm{~m}$ and Elk tests $\mathrm{S}_{\Pi}=16 \mathrm{~m}$ was done in accordance with the diagrams given in the article [4].

The items under test included the Russkaya Mekhanika's oversnow vehicles, models RM Buran Leader, RM Tayga Varyag 550, RM Tayga Patrul 800 SWT, RM Vector 551i and over companies' oversnow vehicles, models BRP Lynx Xtrim Commander 800 E-TEC, Arctic Cat Pantera 7000 XT LTD, Polaris 800 Titan Adventure 155 which characteristics are given in Table 1.

Table 1. Oversnow vehicle main characteristics

\begin{tabular}{|c|c|c|c|c|c|c|c|}
\hline & $\begin{array}{c}\text { RM Tayga } \\
\text { Patrul } 800 \\
\text { SWT }\end{array}$ & $\begin{array}{c}\text { RM } \\
\text { Buran } \\
\text { Leader }\end{array}$ & $\begin{array}{c}\text { RM Tayga } \\
\text { Varyag } \\
550\end{array}$ & $\begin{array}{l}\text { RM } \\
\text { Vector } \\
551 \mathrm{i}\end{array}$ & $\begin{array}{l}\text { BRP Lynx } \\
\text { Xtrim } \\
\text { Command } \\
\text { er } 800 \text { E- } \\
\text { TEC }\end{array}$ & $\begin{array}{c}\text { Arctic Cat } \\
\text { Pantera } \\
7000 \text { XT } \\
\text { LTD }\end{array}$ & $\begin{array}{l}\text { Polaris } \\
800 \\
\text { Titan } \\
\text { Adventu } \\
\text { re } 155\end{array}$ \\
\hline \multicolumn{8}{|l|}{ Engine } \\
\hline $\begin{array}{l}\text { Engine cc } \\
\text { /Cylinders }\end{array}$ & $800 / 2$ & $635 / 2$ & $553 / 2$ & $553 / 2$ & $799.5 / 2$ & $1049 / 3$ & $795 / 2$ \\
\hline Power, h.p. & 60 & 34 & 55 & 67 & 164 & 127 & 154 \\
\hline Chassis & & & & & & & \\
\hline $\begin{array}{c}\text { Transmissio } \\
n\end{array}$ & CVT & CVT & CVT & CVT & CVT & CVT & CVT \\
\hline Brake gear & $\begin{array}{l}\text { Hydraulic, } \\
\text { disc }\end{array}$ & $\begin{array}{l}\text { Mechani } \\
\text { cal, disc }\end{array}$ & $\begin{array}{l}\text { Hydraulic, } \\
\text { disc }\end{array}$ & $\begin{array}{l}\text { Hydraulic, } \\
\text { disc }\end{array}$ & $\begin{array}{l}\text { Hydraulic, } \\
\text { disc }\end{array}$ & $\begin{array}{l}\text { Hydraulic, } \\
\text { disc }\end{array}$ & $\begin{array}{l}\text { Hydraul } \\
\text { ic, disc }\end{array}$ \\
\hline \multicolumn{8}{|l|}{ Suspension } \\
\hline $\begin{array}{c}\text { Type of } \\
\text { front } \\
\text { suspension }\end{array}$ & telescopic & $\begin{array}{l}\text { elliptic } \\
\text { spring }\end{array}$ & telescopic & levered & $\begin{array}{l}\text { A-LFS } \\
\text { with A- } \\
\text { levers }\end{array}$ & $\begin{array}{c}\text { Arctic } \\
\text { Race with } \\
\text { gas shock } \\
\text { absorbers }\end{array}$ & $\begin{array}{l}\text { AXYS } \\
\text { Front } \\
\text { Suspens } \\
\text { ion }\end{array}$ \\
\hline $\begin{array}{l}\text { Type of } \\
\text { rear } \\
\text { suspension }\end{array}$ & slide & $\begin{array}{l}\text { indepen } \\
\text { dent, } \\
\text { spring- } \\
\text { balance }\end{array}$ & slide & slide & $\begin{array}{c}\text { PPS- } \\
\text { 5900-A }\end{array}$ & $\begin{array}{l}\text { XTRA- } \\
\text { ACTION } \\
\text { with } \\
\text { torsion } \\
\text { springs }\end{array}$ & $\begin{array}{c}\text { Titan } \\
\text { with } \\
\text { hinged } \\
\text { extensio } \\
n\end{array}$ \\
\hline $\begin{array}{c}\text { Track, } \\
\mathrm{L} \times \mathrm{W} \times \mathrm{H} \\
\mathrm{mm}\end{array}$ & $\begin{array}{c}3968 x \\
600 x 30\end{array}$ & $\begin{array}{c}2 \mathrm{x} \\
2878 \mathrm{x} \\
380 \mathrm{x} \\
17.5\end{array}$ & $\begin{array}{c}3968 \mathrm{x} \\
508 \times 35\end{array}$ & $\begin{array}{c}3968 x \\
500 x 30\end{array}$ & $\begin{array}{c}3923 x \\
500 x 44\end{array}$ & $\begin{array}{c}3912 x \\
508 x 35\end{array}$ & $\begin{array}{c}3937 \mathrm{x} \\
508 \mathrm{x} \\
45.7\end{array}$ \\
\hline \multicolumn{8}{|l|}{$\begin{array}{c}\text { Dimension } \\
\mathrm{s}\end{array}$} \\
\hline $\begin{array}{c}\text { Oversnow } \\
\text { vehicle } \\
\text { dimensions, } \\
\mathrm{L} \times \mathrm{W} \times \mathrm{H} \\
\mathrm{mm}\end{array}$ & $\begin{array}{c}2990 x \\
1130 x \\
1400\end{array}$ & $\begin{array}{c}2700 x \\
910 x \\
1335\end{array}$ & $\begin{array}{c}2990 \mathrm{x} \\
1050 \mathrm{x} \\
1380\end{array}$ & $\begin{array}{c}3250 \mathrm{x} \\
1270 \mathrm{x} \\
1425\end{array}$ & $\begin{array}{c}3230 \mathrm{x} \\
996 \mathrm{x} 1230\end{array}$ & $\begin{array}{c}3378 \mathrm{x} \\
1270 \mathrm{x} \\
1473\end{array}$ & $\begin{array}{c}3280 \mathrm{x} \\
1220 \mathrm{x} \\
1450\end{array}$ \\
\hline $\begin{array}{c}\text { Dry* } \\
\text { weight, } \mathrm{kg}\end{array}$ & 350 & 285 & 285 & 320 & 318 & 285 & 298 \\
\hline
\end{tabular}

Brought to the tests were samples of the weight including weight of a sample ready for normal operation, filled with fuel and other service fluids, with tools, test-driver's weight of $80 \mathrm{~kg}$ and a weight of measurement equipment.

Purpose of the tests:

-experimentally determine speed and brake properties as well as indicators which characterize stability and controllability of the oversnow equipment.

The comparability tests were conducted in Rybinsk, Yaroslavl oblast, Russia at the horizontal terrain sections with the maximum slope of $1 \%$. The terrain was covered with 
loose snow 12-15 cm deep, the snow was uniform along the entire depth, with a temperature of minus $6{ }^{\circ} \mathrm{C}[5]$.

The tests were conducted in dry windless weather at an ambient temperature of minus 6 ${ }^{\circ} \mathrm{C}$, atmospheric pressure of $748 \mathrm{~mm} \mathrm{Hg}$ and air relative humidity of $86 \%$.

A measurement system Racelogic with software VBOXTools was used during the comparability tests. This system with software makes it possible to record and store data on oversnow vehicle' speeds, accelerations, travel, movement trajectory, etc. Software VBOXTools is based on data processing core ReportGenerator with references to the graphic imaging tools, mapping tools and VBOX setting tools.

The results of tractional dynamic measurements for the oversnow vehicles, models RM Buran Leader, RM Tayga Varyag 550, RM Tayga Patrul 800 SWT, RM Vector 551i and oversnow vehicles BRP Lynx Xtrim Commander 800 E-TEC, Arctic Cat Pantera 7000 XT LTD, Polaris 800 Titan Adventure 155 are given in Table 2.

Table 2. Oversnow vehicle tractional dynamic measurement results

\begin{tabular}{|c|c|c|c|c|c|c|c|}
\hline \multirow{3}{*}{$\begin{array}{c}\text { Oversnow vehicle } \\
\text { model }\end{array}$} & \multicolumn{7}{|c|}{ Parameters } \\
\hline & \multirow[t]{2}{*}{$\begin{array}{l}\text { Maximum speed, } \\
\mathbf{k m} / \mathbf{h}\end{array}$} & \multicolumn{3}{|c|}{$\begin{array}{c}\text { Time } \\
\text { of acceleration to, } s \\
\end{array}$} & \multicolumn{3}{|c|}{$\begin{array}{l}\text { Path of acceleration from } \\
\text { rest to speed building-up, m }\end{array}$} \\
\hline & & $\begin{array}{c}30 \\
\mathbf{k m} / \mathbf{h}\end{array}$ & $\begin{array}{c}60 \\
\mathrm{~km} / \mathrm{h}\end{array}$ & $\begin{array}{l}\text { Max. } \\
\text { speed }\end{array}$ & $\begin{array}{c}30 \\
\mathbf{k m} / \mathbf{h}\end{array}$ & $\begin{array}{c}60 \\
\mathrm{~km} / \mathrm{h}\end{array}$ & $\begin{array}{l}\text { Max. } \\
\text { speed }\end{array}$ \\
\hline RM Buran Leader & 61.42 & 2.59 & 11.74 & 14.27 & 10.53 & 139.5 & 182.92 \\
\hline $\begin{array}{l}\text { RM Tayga Varyag } \\
550\end{array}$ & 81.45 & 1.95 & 4.86 & 12 & 8.66 & 53.7 & 206.5 \\
\hline $\begin{array}{l}\text { RM Tayga Patrul } \\
800 \text { SWT }\end{array}$ & 82.08 & 2.07 & 5.66 & 14.01 & 8.84 & 55.87 & 226.62 \\
\hline RM Vector 551i & 81.48 & 1.93 & 4.79 & 12.46 & 6.92 & 43.04 & 195.28 \\
\hline $\begin{array}{c}\text { BRP Lynx Xtrim } \\
\text { Commander } 800 \text { E- } \\
\text { TEC } \\
\end{array}$ & 104.04 & 1.52 & 3.49 & 8.6 & 6.08 & 31.81 & 155.05 \\
\hline $\begin{array}{l}\text { Arctic Cat Pantera } \\
7000 \text { XT LTD }\end{array}$ & 102.43 & 1.61 & 3.74 & 11.11 & 6.62 & 34.04 & 215.11 \\
\hline $\begin{array}{l}\text { Polaris } 800 \text { Titan } \\
\text { Adventure } 155\end{array}$ & 106.42 & 1.84 & 4.3 & 10.63 & 6.9 & 36.8 & 191.4 \\
\hline
\end{tabular}

The results of braking dynamic measurements for the oversnow vehicles, models RM Buran Leader, RM Tayga Varyag 550, RM Tayga Patrul 800 SWT, RM Vector 551i and oversnow vehicles BRP Lynx Xtrim Commander 800 E-TEC, Arctic Cat Pantera 7000 XT LTD, Polaris 800 Titan Adventure 155 are given in Table 3.

Table 3. Oversnow vehicle braking dynamic measurement results

\begin{tabular}{|c|c|c|c|c|c|c|}
\hline \multirow{2}{*}{ Oversnow vehicle model } & \multicolumn{5}{|c|}{ Parameters } \\
\cline { 2 - 7 } & \multicolumn{5}{|c|}{$\begin{array}{c}\text { Time of braking } \\
\text { from speed, s }\end{array}$} & \multicolumn{3}{c|}{ Braking path at braking from speed, m } \\
\cline { 2 - 7 } & $\mathbf{3 0} \mathbf{~ k m} / \mathbf{h}$ & $\mathbf{6 0} \mathbf{~ k m} / \mathbf{h}$ & $\begin{array}{c}\text { Max. } \\
\text { speed }\end{array}$ & $\mathbf{3 0 ~ k m / h}$ & $\mathbf{6 0 ~ k m} / \mathbf{h}$ & Max. speed \\
\hline RM Buran Leader & 2.1 & 3.94 & 4.02 & 8.36 & 30.92 & 33.49 \\
\hline RM Tayga Varyag 550 & 2.2 & 4.61 & 6.18 & 8.93 & 38.4 & 68.44 \\
\hline $\begin{array}{c}\text { RM Tayga Patrul 800 } \\
\text { SWT }\end{array}$ & 2.68 & 5.05 & 6.58 & 11.37 & 40.98 & 71.15 \\
\hline RM Vector 551i & 2.54 & 4.52 & 5.72 & 10.52 & 34.99 & 58.22 \\
\hline $\begin{array}{c}\text { BRP Lynx Xtrim } \\
\text { Commander 800 E-TEC }\end{array}$ & 1.96 & 3.77 & 5.75 & 8.24 & 30.72 & 74.97 \\
\hline $\begin{array}{c}\text { Arctic Cat Pantera 7000 } \\
\text { XT LTD }\end{array}$ & 2.38 & 4.18 & 6.21 & 9.52 & 31.52 & 76.78 \\
\hline $\begin{array}{c}\text { Polaris 800 Titan } \\
\text { Adventure 155 }\end{array}$ & 2.03 & 3.66 & 5.86 & 8.64 & 28.4 & 76.41 \\
\hline
\end{tabular}


Two maneuvers, namely a test of turn over set radius $\mathrm{R}_{\Pi}=25 \mathrm{~m}$ and an Elk test were conducted to determine indicators characterizing controllability and stability of the oversnow vehicles. The maximum speed of the oversnow vehicles at entry into, recovery from and during the maneuver was measured while conducting the test of turn over set radius $R_{\Pi}=25 \mathrm{~m}$.

The results of the oversnow vehicle speed measurement during the "test of turn over set radius" maneuver are presented in Table 4.

Table 4. Results of the oversnow vehicle speed measurement during the "test of turn over set radius $\mathrm{R} \Pi=25 \mathrm{~m}$ " maneuver

\begin{tabular}{|c|c|c|c|}
\hline \multirow{2}{*}{ Oversnow vehicle model } & \multicolumn{3}{|c|}{ Maximum speed at sections of the Turn maneuver, $\mathbf{k m} / \mathbf{h}$} \\
\cline { 2 - 4 } & At entry & In mid-maneuver & At recovery \\
\hline RM Buran Leader & 41.76 & 29.52 & 36.53 \\
\hline RM Tayga Varyag 550 & 41 & 31.4 & 41.17 \\
\hline RM Tayga Patrul 800 SWT & 36.7 & 35.4 & 30.14 \\
\hline RM Vector 551i & 40 & 29.2 & 32.3 \\
\hline $\begin{array}{c}\text { BRP Lynx Xtrim Commander } \\
\text { 800 E-TEC }\end{array}$ & 42.9 & 23.8 & 34.8 \\
\hline Arctic Cat Pantera 7000 XT LTD & 40 & & 34 \\
\hline Polaris 800 Titan Adventure 155 & 41.8 & 25.4 & 34.6 \\
\hline
\end{tabular}

Maximum speed of the oversnow vehicles at entry into and recovery from the maneuver during the Elk test maneuver.

Results of speed measurements for the domestic and foreign oversnow vehicles during the Elk test maneuver are presented in Table 5.

Table 5. Results of speed measurements for the domestic and foreign oversnow vehicles during the Elk test maneuver

\begin{tabular}{|c|c|c|}
\hline \multirow{2}{*}{ Oversnow vehicle model } & \multicolumn{2}{|c|}{$\begin{array}{c}\text { Maximum speed at sections of the Elk test } \\
\text { maneuver, km/h }\end{array}$} \\
\cline { 2 - 3 } & At entry & At recovery \\
\hline RM Buran Leader & 53.4 & 48.7 \\
\hline RM Tayga Varyag 550 & 68.1 & 64.65 \\
\hline RM Tayga Patrul 800 SWT & 68.16 & 68.03 \\
\hline RM Vector 551i & 69.9 & 67.3 \\
\hline BRP Lynx Xtrim Commander 800 E-TEC & 66.1 & 64.8 \\
\hline Arctic Cat Pantera 7000 XT LTD & 80.1 & 76.2 \\
\hline Polaris 800 Titan Adventure 155 & 76.3 & 73 \\
\hline
\end{tabular}

\section{Outcome}

Acceleration of RM Buran Leader vehicle to speed of $30 \mathrm{~km} / \mathrm{h}$ was $2.59 \mathrm{~s}$, distance covered - $10.53 \mathrm{~m}$. Acceleration of RM Tayga Varyag 550 vehicle to speed of $30 \mathrm{~km} / \mathrm{h}$ was $1.95 \mathrm{~s}$, covered distance $-8.66 \mathrm{~m}$. Acceleration of RM Tayga Patrul 800 SWT vehicle to speed of $30 \mathrm{~km} / \mathrm{h}$ was $2.07 \mathrm{~s}$, distance covered $-8.84 \mathrm{~m}$. Acceleration of RM Vector 551i vehicle to speed of $30 \mathrm{~km} / \mathrm{h}$ was $1.93 \mathrm{~s}$, distance covered - $6.92 \mathrm{~m}$. Acceleration of BRP Lynx Xtrim Commander 800 E-TEC vehicle to speed of $30 \mathrm{~km} / \mathrm{h}$ was $1.52 \mathrm{~s}$, distance covered $-6.08 \mathrm{~m}$. Acceleration of Arctic Cat Pantera 7000 XT LTD vehicle to speed of $30 \mathrm{~km} / \mathrm{h}$ was $1.61 \mathrm{~s}$, distance covered $-6.62 \mathrm{~m}$. Acceleration of Polaris 800 Titan Adventure 155 vehicle to speed of $30 \mathrm{~km} / \mathrm{h}$ was $1.84 \mathrm{~s}$, distance covered $-6.9 \mathrm{~m}$. 
Acceleration of RM Buran Leader vehicle to speed of $60 \mathrm{~km} / \mathrm{h}$ was $11.74 \mathrm{~s}$, distance covered - $139.5 \mathrm{~m}$. Acceleration of RM Tayga Varyag 550 vehicle to speed of $60 \mathrm{~km} / \mathrm{h}$ was $4.86 \mathrm{~s}$, covered distance - $53.7 \mathrm{~m}$. Acceleration of RM Tayga Patrul $800 \mathrm{SWT}$ vehicle to speed of $60 \mathrm{~km} / \mathrm{h}$ was $5.66 \mathrm{~s}$, distance covered $-55.87 \mathrm{~m}$. Acceleration of RM Vector 551i vehicle to speed of $60 \mathrm{~km} / \mathrm{h}$ was $4.79 \mathrm{~s}$, distance covered - $43.04 \mathrm{~m}$. Acceleration of BRP Lynx Xtrim Commander 800 E-TEC vehicle to speed of $60 \mathrm{~km} / \mathrm{h}$ was $3.49 \mathrm{~s}$, distance covered $-31.81 \mathrm{~m}$. Acceleration of Arctic Cat Pantera 7000 XT LTD vehicle to speed of 60 $\mathrm{km} / \mathrm{h}$ was $3.74 \mathrm{~s}$, distance covered - $34.04 \mathrm{~m}$. Acceleration of Polaris 800 Titan Adventure 155 vehicle to speed of $60 \mathrm{~km} / \mathrm{h}$ was $4.3 \mathrm{~s}$, distance covered $-36.8 \mathrm{~m}$.

Acceleration of RM Buran Leader vehicle to a maximum speed of $61.42 \mathrm{~km} / \mathrm{h}$ was $14.27 \mathrm{~s}$, distance covered - $182.92 \mathrm{~m}$. Acceleration of RM Tayga Varyag 550 vehicle to a maximum speed of $81.45 \mathrm{~km} / \mathrm{h}$ was $12 \mathrm{~s}$, covered distance $-206.5 \mathrm{~m}$. Acceleration of RM Tayga Patrul 800 SWT vehicle to a maximum speed of $82.08 \mathrm{~km} / \mathrm{h}$ was $14.01 \mathrm{~s}$, distance covered - $226.62 \mathrm{~m}$. Acceleration of RM Vector $551 \mathrm{i}$ vehicle to a maximum speed of 81.48 $\mathrm{km} / \mathrm{h}$ was $12.46 \mathrm{~s}$, distance covered - $195.28 \mathrm{~m}$. Acceleration of BRP Lynx Xtrim Commander 800 E-TEC vehicle to a maximum speed of $104.04 \mathrm{~km} / \mathrm{h}$ was $8.6 \mathrm{~s}$, distance covered - $155.05 \mathrm{~m}$. Acceleration of Arctic Cat Pantera 7000 XT LTD vehicle to a maximum speed of $102.43 \mathrm{~km} / \mathrm{h}$ was $11.11 \mathrm{~s}$, distance covered $-215.11 \mathrm{~m}$. Acceleration of Polaris 800 Titan Adventure 155 vehicle to a maximum speed of $106.42 \mathrm{~km} / \mathrm{h}$ was $10.63 \mathrm{~s}$, distance covered - $191.4 \mathrm{~m}$.

Braking of RM Buran Leader vehicle from initial speed of $30 \mathrm{~km} / \mathrm{h}$ to a full stop was $2.1 \mathrm{~s}$, braking path $-8.36 \mathrm{~m}$. Braking of RM Tayga Varyag 550 vehicle from initial speed of $30 \mathrm{~km} / \mathrm{h}$ to a full stop was $2.2 \mathrm{~s}$, braking path $-8.93 \mathrm{~m}$. Braking of RM Tayga Patrul 800 SWT vehicle from initial speed of $30 \mathrm{~km} / \mathrm{h}$ to a full stop was $2.68 \mathrm{~s}$, braking path $-11.37 \mathrm{~m}$. Braking of RM Vector $551 \mathrm{i}$ vehicle from initial speed of $30 \mathrm{~km} / \mathrm{h}$ to a full stop was $2.54 \mathrm{~s}$, braking path - $10.52 \mathrm{~m}$. Braking of BRP Lynx Xtrim Commander 800 E-TEC vehicle from initial speed of $30 \mathrm{~km} / \mathrm{h}$ to a full stop was $1.96 \mathrm{~s}$, braking path $-8.24 \mathrm{~m}$. Braking of Arctic Cat Pantera 7000 XT LTD vehicle from initial speed of $30 \mathrm{~km} / \mathrm{h}$ to a full stop was $2.38 \mathrm{~s}$, braking path $-9.52 \mathrm{~m}$. Braking of Polaris 800 Titan Adventure 155 vehicle from initial speed of $30 \mathrm{~km} / \mathrm{h}$ to a full stop was $2.03 \mathrm{~s}$, braking path $-8.64 \mathrm{~m}$.

Braking of RM Buran Leader vehicle from initial speed of $60 \mathrm{~km} / \mathrm{h}$ to a full stop was $3.94 \mathrm{~s}$, braking path $-30.92 \mathrm{~m}$. Braking of RM Tayga Varyag 550 vehicle from initial speed of $60 \mathrm{~km} / \mathrm{h}$ to a full stop was $4.61 \mathrm{~s}$, braking path - $38.4 \mathrm{~m}$. Braking of RM Tayga Patrul $800 \mathrm{SWT}$ vehicle from initial speed of $60 \mathrm{~km} / \mathrm{h}$ to a full stop was $5.05 \mathrm{~s}$, braking path $40.98 \mathrm{~m}$. Braking of RM Vector $551 \mathrm{i}$ vehicle from initial speed of $60 \mathrm{~km} / \mathrm{h}$ to a full stop was $4.52 \mathrm{~s}$, braking path - $34.99 \mathrm{~m}$. Braking of BRP Lynx Xtrim Commander 800 E-TEC vehicle from initial speed of $60 \mathrm{~km} / \mathrm{h}$ to a full stop was $3.77 \mathrm{~s}$, braking path $-30.72 \mathrm{~m}$. Braking of Arctic Cat Pantera 7000 XT LTD vehicle from initial speed of $60 \mathrm{~km} / \mathrm{h}$ to a full stop was $4.18 \mathrm{~s}$, braking path $-31.52 \mathrm{~m}$. Braking of Polaris 800 Titan Adventure 155 vehicle from initial speed of $60 \mathrm{~km} / \mathrm{h}$ to a full stop was $3.66 \mathrm{~s}$, braking path $-28.4 \mathrm{~m}$.

Braking of RM Buran Leader vehicle from maximum initial speed of $61.42 \mathrm{~km} / \mathrm{h}$ to a full stop was $4.02 \mathrm{~s}$, braking path - $33.49 \mathrm{~m}$. Braking of RM Tayga Varyag 550 vehicle from maximum initial speed of $81.45 \mathrm{~km} / \mathrm{h}$ to a full stop was $6.18 \mathrm{~s}$, braking path -68.44 m. Braking of RM Tayga Patrul 800 SWT vehicle from maximum initial speed of 82.08 $\mathrm{km} / \mathrm{h}$ to a full stop was $6.58 \mathrm{~s}$, braking path $-71.15 \mathrm{~m}$. Braking of RM Vector 551i vehicle from maximum initial speed of $81.48 \mathrm{~km} / \mathrm{h}$ to a full stop was $5.72 \mathrm{~s}$, braking path -58.22 m. Braking of BRP Lynx Xtrim Commander 800 E-TEC vehicle from maximum initial speed of $104.04 \mathrm{~km} / \mathrm{h}$ to a full stop was $5.75 \mathrm{~s}$, braking path $-74.97 \mathrm{~m}$. Braking of Arctic Cat Pantera 7000 XT LTD vehicle from maximum initial speed of $102.43 \mathrm{~km} / \mathrm{h}$ to a full stop was $6.21 \mathrm{~s}$, braking path $-76.78 \mathrm{~m}$. Braking of Polaris 800 Titan Adventure 155 
vehicle from maximum initial speed of $106.42 \mathrm{~km} / \mathrm{h}$ to a full stop was $5.86 \mathrm{~s}$, braking path $76.41 \mathrm{~m}$.

Maximum speed of the RM Buran Leader vehicle during the turn over set radius $(R=25$ m) maneuver was $41.76 \mathrm{~km} / \mathrm{h}$ at entry, $36.53 \mathrm{~km} / \mathrm{h}$ at recovery, $29.52 \mathrm{~km} / \mathrm{h}$ in midmaneuver. Maximum speed of the RM Tayga Varyag 550 vehicle during the turn over set radius $(\mathrm{R}=25 \mathrm{~m})$ maneuver was $41 \mathrm{~km} / \mathrm{h}$ at entry, $41.17 \mathrm{~km} / \mathrm{h}$ at recovery, $31.4 \mathrm{~km} / \mathrm{h}$ in mid-maneuver. Maximum speed of the RM Tayga Patrul 800 SWT vehicle during the turn over set radius $(\mathrm{R}=25 \mathrm{~m})$ maneuver was $36.7 \mathrm{~km} / \mathrm{h}$ at entry, $35.4 \mathrm{~km} / \mathrm{h}$ at recovery, 30.14 $\mathrm{km} / \mathrm{h}$ in mid-maneuver. Maximum speed of the RM Vector 551i vehicle during the turn over set radius $(\mathrm{R}=25 \mathrm{~m})$ maneuver was $40 \mathrm{~km} / \mathrm{h}$ at entry, $29.2 \mathrm{~km} / \mathrm{h}$ at recovery, $32.3 \mathrm{~km} / \mathrm{h}$ in mid-maneuver. Maximum speed of the BRP Lynx Xtrim Commander 800 E-TEC vehicle during the turn over set radius $(\mathrm{R}=25 \mathrm{~m})$ maneuver was $42.9 \mathrm{~km} / \mathrm{h}$ at entry, 23.8 $\mathrm{km} / \mathrm{h}$ at recovery, $34.8 \mathrm{~km} / \mathrm{h}$ in mid-maneuver. Maximum speed of the Arctic Cat Pantera 7000 XT LTD vehicle during the turn over set radius ( $\mathrm{R}=25 \mathrm{~m})$ maneuver was $40 \mathrm{~km} / \mathrm{h}$ at entry, $25.4 \mathrm{~km} / \mathrm{h}$ at recovery, $34 \mathrm{~km} / \mathrm{h}$ in mid-maneuver. Maximum speed of the Polaris 800 Titan Adventure 155 vehicle during the turn over set radius $(\mathrm{R}=25 \mathrm{~m})$ maneuver was 41.8 $\mathrm{km} / \mathrm{h}$ at entry, $29.5 \mathrm{~km} / \mathrm{h}$ at recovery, $34.6 \mathrm{~km} / \mathrm{h}$ in mid-maneuver.

Maximum speed of the RM Buran Leader vehicle during the Elk test maneuver was $53.4 \mathrm{~km} / \mathrm{h}$ at entry into the maneuver, $48.7 \mathrm{~km} / \mathrm{h}$ at recovery from the maneuver. Maximum speed of the RM Tayga Varyag 550 vehicle during the Elk test maneuver was $68.1 \mathrm{~km} / \mathrm{h}$ at entry into the maneuver, $64.65 \mathrm{~km} / \mathrm{h}$ at recovery from the maneuver. Maximum speed of the RM Tayga Patrul 800 SWT vehicle during the Elk test maneuver was $68.16 \mathrm{~km} / \mathrm{h}$ at entry into the maneuver, $68.03 \mathrm{~km} / \mathrm{h}$ at recovery from the maneuver. Maximum speed of the RM Vector $551 \mathrm{i}$ vehicle during the Elk test maneuver was $69.9 \mathrm{~km} / \mathrm{h}$ at entry into the maneuver, $67.3 \mathrm{~km} / \mathrm{h}$ at recovery from the maneuver. Maximum speed of the BRP Lynx Xtrim Commander 800 E-TEC vehicle during the Elk test maneuver was $66.1 \mathrm{~km} / \mathrm{h}$ at entry into the maneuver, $64.8 \mathrm{~km} / \mathrm{h}$ at recovery from the maneuver. Maximum speed of the Arctic Cat Pantera 7000 XT LTD vehicle during the Elk test maneuver was $80.1 \mathrm{~km} / \mathrm{h}$ at entry into the maneuver, $76.2 \mathrm{~km} / \mathrm{h}$ at recovery from the maneuver. Maximum speed of the Polaris 800 Titan Adventure 155 vehicle during the Elk test maneuver was $76.3 \mathrm{~km} / \mathrm{h}$ at entry into the maneuver, $73 \mathrm{~km} / \mathrm{h}$ at recovery from the maneuver.

Work has been performed in Bauman Moscow State Technical University with a financial support of the Russian Ministry of Education under Agreement №14.577.21.0272 (Work unified indicator: RFMEFI57717X0272)

\section{References}

1. GOST R 50944-2011 Snowmobiles, Technical requirements and test methods

2. A.S. Diakov, A.Yu. Zakharov, V.E. Klubnichkin, E.E. Klubnichkin, A.B. Kartashov, Experimental estimation of high-speed and braking properties of domestic production of snowmobiles, Proceedings of NSTU. R.E. Alekseeva, 1, pp. 156-164 (2018)

3. F.F. Mukhamadyarov, A.I. Chuprakov, S.A. Romanov, The Construction of Snowmobiles (Textbook, Kirov, 2016)

4. A.S. Diakov, E.E. Klubnichkin, V.E. Klubnichkin, A.Yu. Zakharov, A.B. Kartashov, Experimental assessment of the stability and controllability of domestic production of snowmobiles, Proceedings of the NSTU. R.E. Alekseeva, 1, pp. 148-155 (2018)

5. V.S. Makarov, D.V. Zezyulin, V.V. Belyakov, Snow as a roadway for vehicles, Int. J. of Appl. and Fundamental Research, 4, pp. 21-24 (2014) 